\title{
THE CONSTRUCTIONIST HISTORIOGRAPHY OF GREEK EROTICS
}

\author{
Daniel Barbo ${ }^{2}$
}

\begin{abstract}
The article analyzes the postmodern and foucaultian view of the theoretical field and methodologies of some works of the Constructionist Historiography that engaged with the study of Greek erotic since the 1980s, trying to reveal their ties to the New Cultural History.
\end{abstract}

\section{Keywords}

Construcionist historiography; Greek erotic; New Cultural History; Postmodernity; Michel Foucault.

\footnotetext{
${ }^{1}$ Translated by author.

${ }^{2}$ Postdoctoral Researcher, Capes Fellow. Federal University of Alagoas - Maceió, AL, Brasil. e-mail: danielbarbo@yahoo.com.br
} 


\section{Resumo}

O artigo analisa o olhar pós-moderno e foucaultiano do campo teórico e das metodologias de algumas obras da Historiografia Construcionista que se ocupou com o estudo da erótica grega a partir da década de 1980, tentando revelar seus vínculos com a Nova História Cultural.

\section{Palavras-chaves}

Historiografia Construcionista, Erótica Grega, Nova História Cultural, PósModernidade, Michel Foucault. 


\section{History and fragmentation}

In 1990, there were been published three works that opened the constructionist approach at the convergence of History of Sexuality and Cultural History: The constraints of desire: the anthropology of sex and gender in Ancient Greece, by John J. Winkler, One hundred years of homosexuality and other essays on Greek love, by David M. Halperin and Before sexuality: the construction of erotic experience in the Greek world, edited by David M. Halperin, John J. Winkler and Froma I. Zeitlin. These works were composed, for the most part, by articles written by the respective authors (as well as others, American, French and English authors in the case of Before Sexuality) along the 1980s. The range of essays they blend employs theoretical and methodological postures in full compatibility with Michel Foucault's thought, especially his poststructuralist theories about the erotic behavior in the ancient Greek world ${ }^{3}$. The national diversification of authors who composed that trilogy is a measure, on the one hand, of the extent of approval to the new theoretical and methodological field and, on the other, of the plurality of contributions to the renovated study of eroticism in Ancient Greece. We consider the common commitment of those three works the precursor representative, the carrier even of credentials of foundation movement, of that new approach, fertile and in fruitful expansion, in renewed historiography of sexuality. The importance of this trilogy as a milestone at the confluence of History of Sexuality with Cultural History was discussed by various thinkers in many reviews and criticism ${ }^{4}$. Verstraete, commenting on the importance of the emergence of this trilogy, noted that

Because of its wide-ranging scope and the originality and quality of its scholarship, Before Sexuality must be welcomed as a truly major work, offering a cornucopia of fresh insights and opening up new vistas for further research and reflection. Together with the collections by Halperin and Winkler and the earlier books by Foucault and Dover, it has laid the foundation for a veritable phenomenology of sexuality in the ancient Greek world. (Verstraete, 1991: 293)

Perspectives, methodologies and fundamental interpretive matrices of this body of works were drawn from cultural anthropology, feminist criticism,

\footnotetext{
${ }^{3}$ For the reasoning of the importance of the work History of Sexuality by Michel Foucault as one of the most important theoretical basis for the Constructionist Historiography, which has been addressing innovatively the Greek erotic since the 1980s, see Barbo, "Michel Foucault e a Historiografia Construcionista", 2011; Barbo, O triunfo do falo: homoerotismo, dominação, ética e política na Atenas Clássica, 2008.

${ }^{4}$ See Sutton Jr., 1991/1992; Verstraete, 1991; Thorp, 1992; Dover, 1991; Goldhill, 1991; Laipson, 1992.
} 
French structuralism (Verstraete, 1991: 290) as well as of literary criticism. To analyze the constructionist historiographical matrix, it is necessary to put into perspective the question of cultural identities in the Late Modernity. Stuart Hall distinguishes three very different conceptions of identity that succeed temporally: the Enlightenment subject, the sociological subject and the post-modern subject.

The Enlightenment subject, or Cartesian, was based on a conception of human person endowed with an autonomous and self-sufficient inner core, equipped with the capacity of reason, awareness and action. Although this subject has the ability to develop throughout life, he remained essentially the same, continuous or 'identical' to himself, throughout his existence. With the increasing complexity of modern society, emerge the notion of sociological subject, whose inner core ceases to be autonomous and self-sufficient, since his formation was dependent on his relationship with others and with the outside, which mediated to that subject the values, meanings and symbols of the world he inhabited. The interaction between the self and society would be the creator of identity of this sociological subject.

These first two types of subject, products of Modernity, are conceptualized as having a fixed, essential or permanent identity. The hallmark of modernity, in reference of the relationship between subject and society, it was stability, fixity and oneness. Hall believes that exactly this relationship is crumbling as a result of structural and institutional changes characteristic of Late Modernity, namely, the second half of the twentieth century ${ }^{5}$, especially due to the last process of globalization. These changes are shifting and breaking up (or 'pluralizing') identities by collapsing stability, rigidity and uniqueness of modern relationship between subject and structure. The process of identification, with

\footnotetext{
${ }^{5}$ HALL, 2006, p. 34-46, points out five major advances in social theory and humanities occurred in thought, or that over it had its main impact in the period of Late Modernity, having as the greatest effect the final decentralization of the notions that see the rational subject and identity as fixed and stable (namely, the death of the Cartesian subject): i) the rereading of Marxism by Louis Althusser's structuralism; ii) the re-reading of Freud's discovery of the unconscious by psychoanalytic thinkers like Lacan; iii) the structural linguistics of Ferdinand de Saussure; iv) the 'genealogy of the modern subject' by the French philosopher and historian Michel Foucault; v) the historical birth in the 1960s of identity politics, both as theoretical critique and as social movement, with which each movement appealed to the social identity of their supporters: "feminism appealed to women, the sexual politics to gays and lesbians, racial struggles to blacks, the antiwar movement to pacifists, and so on."
} 
which we project ourselves in our cultural identities, is becoming increasingly temporary, variable and problematic, since the postmodern subject is being seen as "consisting not of a single but multiple identities, sometimes contradictory or unresolved." Therefore, the post-modern subject is conceptualized, in the view of many thinkers, such as not having a fixed, essential or permanent identity. (Hall, 2006: 10-12). The work of Hall explains that

the conceptual shifts by which, according to some theorists, the Enlightenment "subject," with a fixed and stable identity, was de-centered into the open, contradictory, unfinished, fragmented identities of the postmodern subject. (Hall, 2006: 46)

With those structural and institutional changes of the last decades, provocative of decentralization, displacement, disruption and fragmentation in the identity of the subject and in its relation to the structure, what sets, to many thinkers, the new conditions of postmodernity,

The subject assumes different identities at different times, identities which are not unified around a coherent "self." Within us are contradictory identities. pulling in different directions, so that our identifications are continuously being shifted about. If we feel we have a unified identity from birth to death, it is only because we construct a comforting story or "narrative of the self" about ourselves. The fully unified, completed, secure, and coherent identity is a fantasy, Instead, as the systems of meaning and cultural representation multiply, we are confronted by a bewildering, fleeting multiplicity of possible identities, any one of which we could identify with - at least temporarily. (Hall, 2006: 13)

In such conditions, in which "postmodernity deconstructs, delegitimizes, misremembers and mismemorizes the discourse of 'Reason that governs the world' " (Reis, 2003: 73), Reis claims that "the being is constant difference, that is, temporal and inessential, and appears in multiple languages. Without uttering the being, the multiple languages constitute himself transitory and different ..." (Reis, 2003: 73).

The new approach to Cultural History is closely linked to this vision of the mutation of the relationship between subject and structure as well as the subject's own mutation, mutations which create new bases for the statute of the historical knowledge and the historiographical writing. The intellectual, philosophical, conceptual and historiographical route that explains sexuality as a cultural construct emerges from these mutations that lead us to the postmodern condition.

Following Reis' analysis, we verify that this mutation in the statute of history and historiographical writing - fruit of the subject's transmutation and new relationships established between subject and structure, especially in the globalization process - is clearly evidenced by the passage that occurs between the global history (from the 
nineteenth century to the second generation of Annales) and the history in crumbs [L'histoire en miettes] (the third generation of Annales) ${ }^{6}$. The Cultural History seems to be the most successful intellectual enterprise in that process of crumbling history. Reis records the losses and gains that the new way of perceiving reality and temporality and to write history represent and, considering the pros and cons, lists some characteristics of this transition or rupture. We'll follow those characteristics, trying to read carefully Reis' analysis to highlight the postmodern tone of the constructionist historiography and therefore its full compliance with the cultural history. We believe that the procedures described by Hall and Reis, slightly exposed here, overlap, overlie and are therefore complementary. Or rather, make up the two faces of Janus, past and future, of a multiple process. They describe, as a whole, the mutation from modernity to postmodernity, from global history to history in crumbs in theoretical, historiographical and conceptual realm and in the context of the subject and of the relationship between subject and structure, which signals the postmodern conditions of historiographical writing and cultural history.

Thinking about the realm of erotic identities, then a possible conclusion from the observation of the transition from global history to history in crumbs described by Reis in the macro theoretical, historiographical and conceptual level, and of the process described by Hall, a process that he condenses and systematizes from various authors (A. Giddens, D. Harvey, E. Laclau) and is reported here very schematically - that is, the transmutation of the subject and therefore of identities in the course of modernity and late modernity - is the claim that if the essentialist historiography of Greek homoeroticism is grounded in the concept of Cartesian subject (the Enlightenment subject and/or the sociological subject) ${ }^{7}$, the constructionist historiography already reflects (or refers us to) a conception of postmodern subject committed, in this sense, with the so-called New Cultural History.

Starting from different conceptions of subjects and different interactions between subjects and structures, each one of these historiographical arrays produces particular and diversified discourses to establish a dialectical relationship between the erotic categories of the ancient Greek world and the erotic categories of modernity and postmodernity. Common place: the historical narratives, the products of the writing of history and the historiographical trends are linked inexorably to temporalities or, in the words of Koselleck, to the historical times.

\footnotetext{
${ }^{6}$ See Reis, 2003, especially Capítulo 2: Da história global à história em migalhas: o que se ganha, o que se perde?

${ }^{7}$ See Barbo. "Detratores do homoerotismo grego: uma historiografia essencialista".
} 
We note, therefore, that the essentialist historiography is linked to modernity, while constructionist historiography is linked to post-modernity. And among them there are deep differences, for due to the victory, in the last decades, of the globalizing capitalist individualism, it speeds up the fragmentation of the subject (of identities) and of the historical writing (History in crumbs); the historian finds himself unable to speak of the whole, a Global History, totalizing (the illusion of universal), but he can speak of everything (extreme fragmentation prone to inconsistency and loss of logical specificity of the history); and the sense of history (the illusion of philosophies of history) empties increasingly (what horizon of expectation can be expected of fragmented and disconnected histories? The horizon of multifragmented diversity?).

However, when we defend the argument that the narrative of the constructionist historiography is one of the productions of the cultural history of the last decades of the twentieth century, and thus closely linked to the complex displacements caused by post-modern world, or rather, a narrative speaking from post-modernity, we do not consider that the constructionist authors align in some way, in terms of narrative of history, to "a relativist position à la Hayden White" who "see historical discourse as merely a free play of rhetorical figures and as one mode of fictional invention among others." (Chartier, 1997: 8). We totally agree with Roger Chartier (and also, in another methodological record, with Carlo Ginzburg) who recommends

against that dissolution of the status of history as a specific knowledge (a stance often taken as a figure of postmodernism) one must insist forcefully that history is commanded by an intention and a principle of truth, that the past history has taken as its object is a reality external to discourse, and that knowledge of it can be verified. (Chartier, 1997: 8)

The struggles for sexual freedom around constructions of erotic identities, multiplied identities, make up one of the facets of these social changes, of these historical and historiographical changes. In the process, Stonewall, preserving due proportions, had the effect of a "French Revolution" for those struggles: its seismic propagation accelerated the generation of identities; contributed to the production of fragmentation of the subjects. It is evident, then, the impact of this event and its various consequences on the new writing of the history of sexuality, crystallized in what is known by constructionism.

\section{The postmodern vocation of constructionist historiography}

1. Before Sexuality

Revista Heródoto. Unifesp. Guarulhos, v. 01, n. 01. Março, 2016. p. 265-298. 
One of the main articulators of the constructionist approach, David Halperin, in his book One Hundred years of homosexuality and other essays on Greek love, considers this new approach a positioning against the relationship between social practices and culture that advances, in relation to the essentialist tendency, in analysis of expressions, behaviors and erotic experiences in history to rethink and reframe the constitution of 'sexuality' in Modernity and redefine it as an operational category of analysis for the History of sexuality and to propose the method called 'cultural poetics of desire' to analyze the construction of erotic experiences and behavior in history.

Deepening the debate on the articulation between erotic categories and the culture in which they emerge, namely, the cultural determination of erotic categories, the constructionist approach is primarily concerned with the construction of erotic meanings in every society and in every culture. Only in modern Western world such construction is articulated by the categories of 'sexuality'. How to understand the construction of these meanings in societies that haven't established 'sexuality'? The work Before sexuality, thinking about this construction in the ancient Greek world, points out a methodology: the 'cultural poetics of desire'.

The essays collected in this work combine two intellectual traditions. In them, the specific theoretical and methodological concerns from the French practice called les sciences humaines, with its keen eye searching for semiotics and deep structures, mingle with the descriptive and interpretative procedures developed in the Anglo-American tradition of cultural anthropology. (Halperin; Winkler; Zeitlin, 1990: 7) From this intersection were born the techniques of 'cultural poetics of desire'.

This methodology deals with the erotic field of a given society, not as an isolated and autonomous instance of social reality, as an approach that was based on a unitary category of analysis and dated like 'sexuality' could give rise, but as an instance in which is implicated several other cultural aspects and social fields of that society.

Proponents of this approach argue that multiple meanings of erotic life in any society are only intelligible if taken in relation to the whole of the social fabric. Thus, the various authors of the essays that compound the work Before sexuality do not study aspects of the erotics in Greek antiquity as if these aspects formed a separated issue, as if the erotics were an independent variable, whose tremors and events could be described in a linear and coherent narrative with minimal reference to other areas of human interest. (Halperin; Winkler; Zeitlin, 1990: 3)

These authors, cultural historians, redefine conceptually the category 'sexuality'. In this new definition, 'sexuality' is no longer thought of as a unitary category of analysis, essentialist, and is now thought of as one of the languages to define, describe, interpret and negotiate all behaviors, modes, values and perspectives of other cultural fields of society. It becomes a discussion area in which interact many social projects like, for 
example, marriage, politics, housework, heritage, education. Sexuality comes to be thought as a social sphere which undergoes changes. (Halperin; Winkler; Zeitlin, 1990: 4) From this new perspective, then we could still call this field of study History of Sexuality. But only from the wider and deeper perspective of social interaction, of this mutuality network that are the social processes of construction of meanings, one can understand more accurately how happens the construction of erotic meanings in different societies.

According to these new creators of constructionism, this understanding can be achieved through the notion of 'cultural poetics of desire'. First, let's see what these authors call 'cultural poetics'. It refers

To the process whereby a society and its subgroups contruct widely shared meanings - behavioral conventions, social distinctions, conceptual schemes, aesthetic values, religious attitudes, moral codes, gender roles, and paradigms of sexual excitement. These meanings are jointly produced, distributed, enforced, and subverted by human communities. (Halperin; Winkler; Zeitlin, 1990: 4)

This broader building process of cultural meanings includes the formation of erotic identities. Affirming the cultural interdependence between social practices and subjective experiences, then the constructionist approach can speak of a 'cultural poetics of desire': "the erotic experiences of individual human beings are thus, in our view, artifacts that reflect, in part, the larger cultural poetics of the societies in which those individuals live" (Halperin; Winkler; Zeitlin, 1990: 4).

Cultural poetics of desire is therefore a part of the total 'cultural poetic' of a society. Consequently, the constructionist approach seeks to understand the formation of erotic identity of a given society through some research of 'cultural poetics of desire' in process in that society. The essays in the book Before sexuality follow this type of analysis and bring out the multiplicity of views, sometimes conflicting, that shape the fundamental practices and experiences of erotic life in ancient Greece.

The emphasis of this work, the construction of Greek erotic experiences, has become, as that was investigated, a vast territory of many possibilities. Exploring different speeches and erotic behaviors, the work shows a significant portion of erotic diversity in the Antiquity and a bunch of possible evidence available for study. Seen through this cleavage, the ancient Greeks had many different ways of speaking and acting in relation to erotic issues, many unveiling or concealment strategies, many representation or suppression tactics. The work Before sexuality reflects this diversity in presenting a few examples of the work being done in this field.

Verstraete noted in 1991 that "Before Sexuality covers literary, epigraphic, and iconographic material hardly or not at all integrated into the study of sex and gender in 
the ancient Greek world until now." (Verstraete, 1991: 292) The fifteen articles that compound Before sexuality, then focusing on neglected Greek sources, explore symbolic dimensions to transcend sexuality as an issue. In this complex work, the articles of the French authors offer a range of iconographic evidence: The sexual life of satyrs, by François Lissarrague, shows that satyrs' semi-human extravagances portrayed on Attic vases express standards for human sexual behavior; From Ambiguity to Ambivalence: The Dionysiac Excursion through the 'Anakreontic' Vases, by Françoise Frontisi-Ducroux and François Lissarrague explains the 'anakreontics' komoi portrayed in pots as a Dionysian mediation of the disorder caused by the 'strangeness / otherness', by signs of femininity and externality. This article has the most detailed iconographic scholarship in the collection and comes to a convincing structuralist interpretation of androgynous male figures in some komoi scenes in the painting of Greek vases; Aspects of Baubo: Ancient Texts and Contexts, by Maurice Olender examines costumes and texts on Baubo, an obscene and humorous genital figure who merges female sexuality with the nurturing and frightening affectations of the old nurses. (Sutton, Jr., 1991/1992: 190; Verstraete, 1991: 292)

The Future of Dreams: From Freud to Artemidoros, by SRF Price, compares Freudian's analysis of dreams with Artemidoros's. Price's article shares common ground with Winkler', Unnatural Acts, the first of his work The Constraints of Desire. Both show that the dynamic-sexual interpretation of dreams has no counterpart in Oneirocritica of Ancient Greece, which was largely concerned with the explanation of health and of the dreamer's future political status, to the point that even the sexual symbolism of dreams was decoded within the limits of this prediction structure. The Semiotics of Gender: Physiognomy and Self-Fashioning in the Second Century CE, by Maud W. Gleason, examines gender stereotypes in physiognomic and astrological texts to discover rules that decode the effeminate man's encrypted behavior (cinaedus). The ancient pseudoscience of physiognomy survived in the West until after the Renaissance. While The Medical Writers' Woman, by Ann Ellis Hanson, an article that makes use of a medical and gynecological literature shows that ancient gynecology recognized the hymen, Maidenhood without Maidenhead: The Female Body in Ancient Greece, by Giulia Sissa, argues the opposite, since such tangible evidence was disregarded in favor of more reliable signs of virginity. Sissa's article combines medical and gynecological literature with other ancient sources, such as mythology, history and ethnography.

The Poetics of Eros: Nature, Art, and Imitation in Longus' Daphnis and Chloe, by Froma I. Zeitlin, sees the treatment of eros in Daphnis \& Chloe as a sophisticated piece through the familiar dichotomies nature/culture and art/life. From Sex to Politics: The Rites of Artemis and Dionysus Aisymnetes Triklaria at Patras, by James Redfield, believes that a mythical-ritual complex in Patras involving Artemis and Dionysus puts politics as the answer to the problems of sex. Putting Her in Her place: Woman, Dirt, and Desire, by 
Anne Carson, finds out in texts that describe women as being wet, wild, fluid and polluting, a conception of femininity design as a dangerous unlimited and in lack of limitation, which would be provided by marriage and by the veil.

Again, as in his book Eros the Bittersweet: an Essay, published in 1986, Carson presents a sharp and penetrating analysis, although it continues to ignore the feminist writings, which could relativize the Greek misogyny. Herakles: The Super-Male and the Feminine, by Nicole Loraux, considers masculine and feminine contradictory elements in the hero Heracles, putting into focus particularly his belly, his tunic and his relationship with Hera. One ... Two ... Three ...: Eros, by Jean-Pierre Vernant, considers eros as a mediator between the person and the others, regarding Plato, Dionysus, Narcissus and Plotinus. Bodies and Minds: Sexuality and Renunciation in Early Christianity, by Peter Brown, describes new alignments between the person, sex and society that emerged with Christianity. Brown's article is a pointed reminder of the main theses of his book The Body and Society, published in 1988. (Sutton Jr., 1991/1992: 190; Verstraete, 1991: 292)

What is noticeable also in these articles is both a practice of specialization at the expense of synthesis as a practice of description/observation/relativism at the expense of explanation/concept. Still following Reis' analysis, we note that the authors of Before Sexuality

find it impossible to reconcile overview with scientifically conducted study; [...] Defend the problem-based history, which can only control its object if delimits it the most; [...] Believe that one can only formulate a manageable problem and a sustainable hypothesis and develop a diverse and sufficient documentation if there is an expertise by the historian, because you can not scientifically know the whole, only the part. (Reis, 2003: 92)

[...] Are suspicious of a holistic science, which would be a contradiction, for the scientific discourse self-regulates avoiding the total approach and delimiting, limiting, assuming a moderate relativism, which is possible only in the fragmentation and specialization. (Reis, 2003: 93)

2. The constraints of desire

In his work The Constraints of Desire: The Anthropology of Sex and Gender in Ancient Greece, published in 1990, John J. Winkler argues that Greek women-citizens, in general, had a much greater degree of autonomy than the social protocols, endorsed by male prescriptive public speeches ${ }^{8}$, made the researchers of ancient Greek world

\footnotetext{
${ }^{8}$ Winkler. Laying down the law: the oversight of men's sexual behavior in classical Athens. In: Halperin; Winkler; Zeitlin, 1990. In this essay, Winkler argues that "The social and editorial conventions within which most public speaking and published writing took place tended to
} 
suppose. These protocols or the usually unspoken assumptions "that govern the strength of public statements, and it seems that much of men's chatter and gossip about women and about themselves" (Winkler, 1994: 16) - that is, the androcentrism were, says Winkler, a calculated farce. The key elements of these protocols are that

sexual contact is understood in public contexts as male-initiated, phalloscentered, and structured around the act of penetration; all acts that conform to those protocols are relatively non-problematic (kata nomon); the only acts for which a general horror could be assumed are incest and oral-genital contact; and, lastly, there is an implicit presumption that sexual identity does not organize the person but is peripheral to the central goals and worries which are focused on survival, public status, jockeying for place in social hierarchies at the expense of fellow competitors, the stability and prospering of patriarchal families in a hostile environment. (Winkler 1990: 43)

There was, therefore, with regard to the condition of freedom and autonomy of these women-citizens in relation to men, a great gap between the androcentric protocols and the social reality. "Were the ancient Greek women (which usually means those of Classical Athens) treated only as something better than a slave or had they an honorable, respected and protected place in society?" (Winkler, 1994: 15)

Winkler notes that the most common assertion in modern historiography of female submission so widespread in the Greek world can be relativized from the reading of excerpts from works of authors like Longo, Homer and Sappho, since

As such the convention of androcentrism is a limited language of men in certain conditions; it does not adequately represent the entire social world as we would like to describe it, but rather serves to mark off a restricted area of importance (that of public transactions) and to speak of it in absolute terms as if it were the whole. [...] Mediterranean androcentrism is both an unquestionable truth as a universal fib. (Winkler 1994: 17)

Demarcating what Winkler calls androcentric protocols is to highlight a representational field of the Greek world that links the three recordings of reality displayed by Chartier, with regard to the domain of erotics and genre with full reference to public space and politics by checking its validity and its scope of breadth, decoding the reach of its truth and its fictional background. The verification of this finding runs through the articles

give voice to a select group of adult male citizens and to mute the others - female, adolescent, demotic (working persons with a minimum of leisure), metic (noncitizens). Those conventions are well known and roughly correspond to proprieties still observable in the family of cultures around the Mediterranean basin”, p. 173. 
collected in this work of Winkler, which, divided into two parts (Andres and Günaikes), has as central point some aspects of sex and gender in ancient Greece analyzed from an anthropological perspective.

The methodological instrumentation acquired by the author with the techniques of social and cultural anthropology, particularly like the feminists practice them, indicates to him a way to make a richer and more complete analysis of sex and gender in societies of ancient Greece, beyond what can inform us, about these subjects, the protocols detected in works of various Greek authors. Also, feminist and gay studies are references used to understanding "that past societies can be studied not for its value to make a political statement about the present, but for its complete and amazing difference" (Winkler, 1994: 15).

Trying to answer the question what is Cultural History?, Peter Burke makes a little consideration about the work The Constraints of Desire, including Winkler on the list of new cultural historians. About one of the outcome of the work, Burke says:

In the case of Ancient Greece, a classicist inspired by cultural anthropology, John Winkler, has shown that although the surviving sources are almost entirely the work of men, they may be read against the grain to reveal distinctively feminine views of sex and other matters. He treats Sappho's lyrics and the female festival of the Adonia as particularly valuable evidence of 'a different consciousness on the part of Greek women concerning the meanings of sex and genre from those enunciated by their husbands and fathers" (Burke, 2005: 41)

The project to analyze the cultural constructions of gender and sex takes Winkler to the issue of cultural construction of identities in history. Regarding the study of sexuality, Winkler proposes anew the questions of Rosalind Coward:

Why is the study of sexuality when it appears in the social sciences frequently subsumed under studies of institutionalized (social) forms of sexual regulation, like marriage? Why is there no theory of forms of domination and inequality in the dynamic of sexual relations? Why is there no understanding of the construction of sexual identity or consideration of the distribution of power and status which this identity might entail? (Rosalind Coward apud Winkler, 1994: 15-16)

In The Constraints of Desire, Winkler avoids for the set of essays any unifying approach that tends to simplification. Rather, let them follow their own logic so that, together, can reproduce the diversity of perspectives and experiences, which comes in harmony with your intuition that

this is in keeping with the insight that both a traditional history-of-ideas approach and a structuralist approach fail in certain ways to do justice to their object. The former does not capture the practices of real people, intellectuals included, while the latter, with its emphasis on system and 
regularity, misses the contest and conflict of a society with multiple centers of authority and a high sense of bluff and the unspoken. (Winkler 1994: 23)

The division of the book in the parts Andrés and Günaikes and sequence of the seven essays and appendices follow a logic that relates to the specificities of sexual and gender identities in the Greek societies. In the first article, 'Unnatural acts: erotic protocols in Artemidoros' analysis of dreams', the work of this Greek author guides Winkler in the analysis of the protocols of the androcentrism, the allocentrism and the invasion, since Artemidoros ${ }^{9}$ is to Winkler the best witness of the verification that "of all the meanings and aspects of sexual behavior that could be singled out to give them special attention, the Greeks focused strongly on domination and submission, just as they are constituted by the phallic penetration." (Winkler, 1994: 23) Winkler makes certain statements about the social both to characterize the fundamental protocols and to show the limits of its application to real life. In proposing that strategy, the author, of course, refuses to reconstruct the cultural history of sex simply or primarily in terms of ideas, but in terms of social practices in conflict. For this purpose, in that anthropological approach, he "[...] uses Artemidoros' Oneirocritica (The interpretation of Dreams) to put into relief the basic principles of the meanings used by Greek-speaking men of the Mediterranean basin in Antiquity to interpret sexual acts." (Winkler 1994: 32)

As an introduction to his analysis of Artemidoros' work, Winkler identifies the cultural facet disguised in what many Greek and Latin authors call 'nature' to talk about sex. As he himself says when analyzing certain passages: "where it says nature, read up culture" (Winkler, 1994: 29). So, Winkler warns us that in the speeches made by these authors about sex, what they considered natural or attributed to nature was, in fact, cultural, non-universal, dated, "conventional and appropriate" (Winkler, 1994: 29). Thus, in human behavior contexts, 'unnatural' usually means 'seriously unconventional', delimiting moral territory. The very contrast phüsis/nomos or nature/culture, a product of the sophistical enterprise of the fifth century BC,

[...] is itself a cultural item, a format of thought once newly discovered, which thereafter spread and eventually was enlisted as a weapon in a historically specific cultural struggle (now called the Enlightenment). Over time it has become an automatic cliché, a deeply embedded habit of the sort

\footnotetext{
${ }^{9}$ Artemidoros Ephesus or Artemidoros Daldianus was a professional soothsayer of the second century AD. He is known for his famous work, in five volumes, entitled Oneirocritica (The Interpretation of Dreams). According to Artemidoros, part of the material of his work was collected from various soothsayers he had met during his long journeys by Greece, the Italian Peninsula and Asia. Other sources were his predecessors, of which sixteen are nominally cited in his work.
} 
that is almost (as we say) a second nature, such that we can hardly imagine not thinking in those terms. This is to say that although it seems natural to us to discuss sex in terms of nature and 'unnature', the 'naturalness' of these categories is itself a sort of cultural illusion. Like sexuality, 'nature' (as applied to sex) has a history. (Winkler, 1994: 30)

Among many examples of this kind of discourse in the Greek world that Winkler investigates to demystify the "natural", decoding their "cultural" base, we have an example in Plato's Laws, which, according to the historian, seem to inaugurate the condemnations to the practices of pederasty:

Plato's spokeman in the Laws (835B-842A) toys with the idea of inventing a social order that would conform to 'nature' as Greek society supposed it was before Oidipus' father Laios invented paederasty. To do so would require a massive restructuring of common belief and practice, placing paederasty on a pair with incest so that everyone acquired a horror of it. Plato's legislator confesses his idea to be a pipe-dream. Yet even though that dream, or rather nightmare, came true - and did so in the very terms employed in the laws, with paederasty coming to be stigmatized as 'unnatural' - what should stand out about Plato's text is the despair there felt about the impossibility, almost the inconceivability, of the project. It was clearly a thoughtexperiment on the same order as censoring traditional poetry in the Republic, one that went utterly against the grain of the values, practices, and debates of Plato's society. These speculations of Plato are unrepresentative - not the opening move in a new game of moralizing sex and hence only obliquely useful for writing the history of a society's sexual mores and practices. (Winkler, 1990: 18-19)

There are analogies between Artemidorian and Freudian interpretation, putting them in an interesting mirror relationship. Both divide the human mind into consciousness and unconsciousness. Both consider dreams as natural activities of the psyche and dreams consist of putting a veil over significant feelings by condensation and displacement to a symbolic language whose elements are extracted from the immediate associations of the dreamer. They differ, however, on two key points.

In first place, in the Artemidorian interpretation, the action of the soul in the dream targets the near future of the dreamer. The unconscious mind knows the transcendental changes that are about to happen. The interpreter's role (Artemidoros) is to help the dreamer to do a reading of the premonitory dream content. In the Freudian interpretation, the target is the distant past of the dreamer. The unconscious mind is harassed by remote facts of childhood. The interpreter's role (Freud) is to help the dreamer to understand or face internal emotional states.

In second place, although in both systems the theories of structure, the operation of the soul and the interview practices to customers are similar, there is a big difference in the culturally determined value which is attributed to sex. (Winkler 1994: 39-43) 
Oneirocritica puts continually on display common social assumptions and shows the operation of androcentric protocols and others based on the sex and gender, but remaining outside them, escaping from the limitations imposed by habitual inclinations of a Dion, Philon or Plato's moralist or elitist texts. Winkler believes that the theory and practice of Artemidoros' work, unlike moralists and elitist's works, are free from prejudice and trends that are commonly present in any ancient author who transmits and evaluates social information. "Artemidoros' empirical stance allows us to grasp a general semantics of sex in the ancient world usually obscured by the tendentious treatment of the moralists" (Winkler, 1990: 43). The work has a tremendous value to reconstruct the parameters of the ancient sexual practice because its categorization of sexual acts, of broad dissemination and long lasting, corresponds to the public perception of the meaning of sexual behavior, provided that:

The most important feature of Artemidoros' interpretive system is his working principle that the symbols and associations of a coded dream are drawn by the soul from the individual dreamer's own cultural experience, not from a universal Book of Meanings or from the language of the gods. (Winkler 1990: 28)

In most cases, apart from unique and individual dreams, he naturally finds himself dealing with the whole range of common, public associations and evaluations which makes him an excellent source for information about daily life in the ancient world. (Winkler 1990: 30)

Thus, an interpreter of dreams like Artemidoros, for the success of his profession, should know the customs, the culture and the symbolic codes of the people his clients belong to. That is, he must be a participant-observer, since Artemidoros,

like an anthropologist he shares the life of the people he studies, trying at once to get inside people's feelings and behaviors and also to stand outside them. (Winkler, 1990: 31)

like the participant-observer he both enters as deeply as possible into the mind and behavior of his informant and at the same time interprets his informant's words and deeds in terms not necessarily shared by or even accessible to the informant. (Winkler, 1990: 33)

This interpretative axiom requires the interpreter to distinguish among the conventions (ethe) those that are universal of those that are specific to a local culture. Thus,

Thracians who dream of tattooing are telling themselves something different from Getai who dream of tattooing, since among Thracians tattooing is a sign of noble birth, whereas among the Getai it is a sign of slavery. (Winkler 1990: 28)

It also requires the interpreter to know the identity specificities of each dreamer, whether wealth, social and marital status, occupation, health, age and the like. The 
meaning of 'becoming a bridge' in a dream varies depending on the dreamer's identity. According to Artemidoros' interpretation:

Someone dreamed that he became a bridge: he became a river ferryman serving the same function as a bridge... However, a rich man dreamed he became a bridge: he was despised by many and thus was (as it were) trampled on. If ever a woman or a handsome lad sees this dream they will become prostitutes and receive many onto themselves. A man involved in a lawsuit who sees this dream will rise above his adversaries and the judge himself, for the river is like a judge in that it does what it wants with impunity, but a bridge is above a river. (Winkler 1990: 29)

It's clear that Winkler's research is entirely in line with the procedures of the writing of history on the basis of the postmodernist historiography, forged under the urgency and regency of the postmodern subject. In another example,

[...] Cunnilingus and felatio between husband and wife are terribly ominous dream-acts, but not for two particular of Artemidoros' acquaintance who merely liked that sort of thing. "They simply saw what excited them." (Winkler, 1990: 29)

Following Artemidoros' interpretations, what interests Winkler is to explore "the axiom that dream-images are determined in principle by the individual's own contingent experiences and associations, rather than by universal or divine connections laid down ahead of time" (Winkler, 1990: 29). He's interested in investigating the diversity of cultural identities of the Greek world from the perspective of identity fragmentation (method of cultural anthropology in the face of the new socio-cultural reality that emerged after the 1960s) that escapes the androcentric protocols, not the illusory universal structures that speak more from the culturally imposed ideas by elites than the real life. Artemidoros' work allowed him such theoretical and methodological development:

This lengthy discussion of Artemidoros' methods and principles has been necessary to lay the groundback for my reading of his pronouncements about sexual events in dreams. The value of his text for us depends on our confident realization that it represents not just one man's opinion about the sexual protocols of ancient societies but an invaluable collection of evidence a kind of ancient Kinsey report - based on interviews with thousands of clients. (Winkler 1990: 33)

Winkler accepts Foucault's statement (History of Sexuality) on the schemes of evaluation described in Oneirocritica. Artemidoros' Dreams analysis

let us see certain generally accepted schemes of evaluation. And one can affirm these are very near to the general principles which already in the classical period organized the moral experience of aphrodisia. Artemidoros' book is therefore a landmark. It testifies to a scheme of thinking that was long-enduring and current in his day. (Foucault apud Winkler, 1990: 43) 
The American historian draws some great conclusions from the study of Oneirocritica in relation to the erotic sphere of the ancient Greek world of the second century AD, which form the basis for the analysis of men's sexual behavior made in the subsequent article entitled 'Laying down the law: The Oversight of Men's Sexual Behavior in Classical Athens'.

Firstly, Oneirocritica has a wide range of information on the perception of the public meanings of sexual activity. Artemidoros' craft, as an anthropologist of dream meanings, establishing an empirical stance on the substance of premonitory dreams of his customers, allows him - in his interpretations of symbols in a ventriloquist operation between signifiers and meanings - both to highlight the consistency and extent of the androcentric protocols and to escape them by rejecting value judgments and preconceptions that Winkler denounces in the moral and elitist/intellectualists authors. Secondly, when operating with the category 'nature', the work demonstrates once again what Winkler had already identified and analyzed in other Greek authors, that is, 'nature', for the cited Greek authors that express contexts about sex, means 'culture'. The fundamental protocols that determine the field of sex meaning are seen by Greek authors as being part of 'nature'. 'Nature' "assumes that what are significant in sexual activity are (i) men, (ii) penises that penetrate, and (iii) the articulation thereby of relative statuses through relations of dominance. [...] 'nature' once more turns out to stand for 'culture'" (Winkler, 1990: 39-40). However, says Winkler:

Artemidoros uses the word 'nature' not as a value judgment but as a category term to mark an important boundary in this field of social signification. By 'unnatural' he simply means that certain acts are either impossible or irrelevant, that is, they are insignificant within the terms of the social meaning of sex. Thus, Artemidoros in his own way illustrates once more the theme that 'nature' means culture, but with the interesting twist that culture (his 'nature') includes both the conventional (kata nomon) and the unconventional (para nomon), for both categories fall under 'natural' (kata phusin). (Winkler 1990: 43)

Bearing in mind those general conclusions, Winkler, in his article Laying down the law, proposes to examine the social transactions by which the deviation from the androcentric protocols had articulated, inspected and managed, in regard to men's sexual behavior in the higher layers of the Athenian citizenship between the years 430 and 330 $\mathrm{BC}$, focusing on the daily functioning of the community and in particular their selfcontrol practices. (Winkler, 1994: 59) 
For this purpose, Winkler makes a survey of the various cultural images of correct and incorrect virility expressed in the agonistic character of the Athenian public sphere ${ }^{10}$. There he analyzes mainly the limits of the application in the social practices of a characteristic convention of this public sphere: the zero-sum competition in the honor/shame system in disputes and public debates. (Winkler, 1994: 61) This public competitiveness has as one of its parameters the hoplites vs. kinaidoi ideology. The hoplite and kinaidos are the personifications, respectively positive and negative, of the fundamental protocols. This polarization reveals the representation of masculinity in the tension between the positive behavior of the figure of the hoplite (soldier-citizen with possessions enough to get the panoply) and the negative behavior of the figure of the kinaidos (powerful image of a man whose social and erotic behavior was deviant in so far as it violated the dominant social definition of masculinity idealized in the figure of the hoplite). While the hoplite is the representation of the ideal masculinity that every citizen in search of honor aims, the kinaidos, always the victim of mockery, scorn or indignation, is the representation of the dreadful feminization that constantly hangs around the reputation of the citizen, whenever he starts losing his own morality. (Winkler 1994: 59-60)

Against an enemy army at war, the spirit of solidarity prevailed among the Athenian soldiers. But within the polis, the competition among citizens in the public spaces could be atrocious, particularly among the most influential, the most enterprising, the most conspicuous and the youngest. And the political and legal competition in those public spaces, whether in the agora, in the assembly or in the courts, was organized in accordance with the same canons of virility, bravery and pride expressed by the ideal of masculinity of the hoplite at war with the enemy. As Winkler proposes, cockfight, an activity widely practiced in Classical Athens, is a very appropriate metaphor to represent the disputes in the high-society circles in the public space of Athenian democracy. The ensemble of forensic speeches of Aeschines and Demosthenes, for example, nicely illustrates that aggression necessary in a direct democracy environment. To survive in this environment, a citizen should demonstrate a hoplitic virility.

${ }^{10}$ The Athenian constitution provided rigorous audits of accounts and acts of public officials (dokimasía and dokimasía rhetoron) at the end of the office, giving ample opportunity for any citizen to bring charges against any act of their administration. These opportunities were constantly used by political enemies to blackmail and malicious attacks. That is the case, for example, of the charge that Aeschines made against Timarchus, though he did not consider himself a sycophant (sykophántes): "I have, as I believe, shown myself a quiet and modest man" [Aeschines, Against Timarchus, 1]. The Reading of a legal piece like Against Timarchus reveals the amplitude and the fierce forensic competitiveness content in Athens along the IV century BC. 
A citizen could be accused of abandoning his responsibilities both by a public scrutiny moved by the state and by a process initiated privately. Among these responsibilities, in the frames of that system of cultural images in force in the public discussions about the appropriate behavior of a soldier-citizen, it was prescribed, in regard to the erotic behavior, an established moral conduct as appropriate to the hoplitic virility. But the laws referring to erotic morality were formulated not in terms of effeminate deviation (katápygon, eurýproktos, kinaidos), which was not, as such, actionable legally in Athenian courts, but in terms of prostitution (hetairekós, pórnos, peporneuménos). The charge of prostitution, as in the case of Timarchus, was formalized into three components not clearly discernible at an effeminate act: promiscuity, venality and passivity to phallic penetration.

Only the most influential citizens in the political management of the State, however, used to employ such legal resources, which were used as weapons to take down their opponents in the public arena. The components of that small elite considered themselves the representative of the highest levels of masculinity. Especially for a man of this group of citizens, to display no bravery (Andreía) would provide him a symbolic lowering of his manhood that could launch him to the class of women. (Winkler, 1994: 60)

In this sense, the virility of the citizens is always to the test in the public competitions, at the constant danger of sliding into the servile or female. Besides, male and female do not participate in a single opposition as the two sides of a coin. Among them, there's a continuum that can be crossed, like a rainbow. A gradation which goes from the hoplite, crosses the various nuances of feminization, the categories of prostitution, and reaches the lower pole of the scale of citizenship: the woman. Moreover, female identity is not only the opposite of male identity. It's also its constant threat. This fundamental polarity between man and woman establishes an infra-masculine polarity represented by the contrasts hoplite vs. kínaidos and politically active citizens (politeuómenos) vs. prostitute (hetairekós, porn, pepornéumenos). The contrast between hoplite and kinaidos reflects a more fundamental polarity that the Greeks established between men and women. That is, the cultural polarity between the genders acts internally on one of them, creating a set of infra-masculine polarities between hoplite and kinaidos. This observation of the male person reversibility in this ancient world, threatening him 
constantly in danger of slipping into the servile or female, had already been advised by Stephen Greenblatt ${ }^{11}$ in his book Fiction and Friction. (Winkler, 1994: 65)

This cultural image of the hoplitic virility prescribes for men the need to exercise desires in a way one should demonstrate mastery over himself and over the others. Since that erotic activity is a symbolic act of zero-sum competition, the hoplite wants to dominate and the kinaidos wants to be dominated. According to the penetrator and penetrated polarization, it was assumed that the kinaidos figure expressed the desire to be penetrated, what assimilated this figure to the female role. (Winkler, 1994: 67)

Therefore, the haughtiness of a masculinity shaped in war role was a key element of honor at the high political competitiveness of the upper echelons of the Athenian public life. To knock down a public opponent, it wasn't uncommon pollute his private life and erotic behavior, just as did Aeschines in his charge against Timarchus, and as did many other rhetorician, speakers and politically active citizens. The rhetorician Aeschines testifies this practice explicitly: "Thus it appears, fellow citizens, that what is so frequently said of public suits is no mistake, namely, that very often private enmities correct public abuses" (Aeschines, Against Timarchus, 2)

In this analysis of the cultural images in which men's sexual behavior is subjected to constant surveillance under the Athenian public sphere, Winkler warns how far the ideal erómenos, the youngest partner of paederastic relationship, is from both the categories of male prostitution as the kinaidos' cultural image:

We are obviously in a different scope of the romantic pursuit of teenager rods by young men of twenties and thirties, known as pederasty, a well illustrated activity on Athenian vases of the late sixth century and the beginning of fifth and portrayed in the Platonic dialogues as an experiment sometimes poorly, sometimes delicious, but always of general interest and approval. In Pederasty, as carefully shown by Dover [Greek Homosexuality], Golden [Pais, Child and Slave] and Foucault [The History of sexuality: The Use of Pleasure], several conventions were combined to protect the younger member of the couple from the stigma of feminization, from being a kinaidos. (Winkler, 1994: 68)

The paederastic relationship (erastés/erómenos) is, of course, closely linked with those cultural images. Through it, cross the mechanisms of the strategy of the socio-political game structured by the androcentric protocols to the extent that (i) the erómenos, while potentially politeuómenos (politically active citizen), participates, in theory, in a

${ }^{11}$ The American literary critic and theorist Stephen Greenblatt is considered by many one of the founders of the New Historicism, a set of critical practices that he himself refers to as Cultural Poetics. 
pedagogical relationship; (ii) in general, the erotic behavior of male citizens, but especially of the politeuómenos and the youth, are constantly monitored by hoplites vs. kinaidoi ideology; (iii) the erotic relationship between erastés and erómenos whether, on the one hand, must preserve erómenos' masculinity, on the other hand, it reproduces the relations of sociopolitical power.

Then, the social symbology and the character of collective representation of the protocols are revealed, what encourages Winkler to search discursivities that enables him to rethink the borders of female autonomy and to reveal women's views on sex and other issues in an androcentric/phallocentric society on the edge, in some Greek discourses, of misogyny. The Cultural History and Literary Criticism require him to decode in undeniable truth and universal lie the representational strategies that mark out and oversee the sexual behavior of Athenian citizens of high public sphere in their cultural images: hoplites vs. kinaidoi ideology, the zero-sum competition, the honor/shame system of morality and the inframasculinity. The condition of the postmodern subject, obsessed by multiple and contradictory identities in variable displacements, moves his interest towards the identity diversity in its flow between the real and the idealized, the imagined, the represented in the very Greek world: erastés, erómenos, hoplíte, kínaidos, hetairekós, pórnos, pepornéumenos, erotic identities now visualized by a decentralization ignored by the short-sighted essentialist view that has seen homosexuality and heterosexuality in Ancient Greece and has been unable to think seriously about the otherness of self.

Unmask natural assumptions about sex and gender as deeply cultural - where it says natural, read cultural - is an achievement of Cultural History. It's with this same anthropological look that he can analyze the Athenian pederasty, that is, the relationship erastés/erómenos, in its specificity, in its otherness, delimiting its deep differences from the modern category of homosexuality.

3. One hundred years of homosexuality

Retaking the Foucaultian thesis of the construction of sexuality, the essays in the book One hundred years of homosexuality by David M. Halperin gravitate around the theme of erotics of male culture in classical antiquity, in particular, in the ancient Greek world. The main objective of the work is

[...] to examine more closely the many respects in which Greek sexual practices differ from "our own" [...] to devise an interpretation of erotic experiences in classical antiquity that foregrounds the historical and cultural specificity of those experiences. (Halperin, 1990: 1-2)

In macro theoretical terms, the rejection of a global history (the non-totality) and the emphasis placed on fragmentation (the non-system) have already been set out in the preface of the book. These essays, Halperin says, 
Do not constitute a comprehensive and systematic treatment of that (large) topic. Rather, they focus on selected aspects of it and explore a variety of issues that have emerged from modern efforts to elucidate it. (Halperin, 1990: ix)

The work does not have an exclusive essay on the Athenian pederasty, although the author does a brilliant analysis of it. Instead, Halperin had inquired

into the wider social components and contexts of "Greek love", believing as I do that we may come to a more satisfactory understanding of classical Athenian paederasty if we do not view it as an isolated, and therefore, "queer", institution but if we regard it, rather, as merely one strand in a larger and more intricate web of erotic and social practices in ancient Greece, ranging from heroic comradeship to commercial sex. The result of this shift in emphasis, I hope, will be to broaden the scope of the study of the erotics of male culture in ancient Greece, to distance that study from the modern medical/forensic/social-scientific category of homosexuality. (Halperin, 1990: ix)

The work is divided into two parts: the essays of the first part [1. One Hundred Years of Homosexuality; 2. "Homosexuality": A Cultural Construct (An Exchange with Richard Schneider); 3. Two Views of Greek Love: Harald Patzer and Michel Foucault] are largely theoretical and refer to a number of issues related to the scholarly method and the current critical practice. The essays of the second part [4. Heroes and Their Pals; 5. The democratic body: Prostitution and Citizenship in Classical Athens; 6. Why is Diotima a Woman?], are examples of literary criticism and historical analysis that extend some of the principles contained in the previous assays for a number of specific problems in the interpretation of Greek culture. (Halperin, 1990: 9)

In the first essay, One Hundred Years of Homosexuality, Halperin investigates the appearance of the neologisms "homosexual" and "homosexuality" in the nineteenth century, showing that the most commonly used term in that century referring to erotic contact between same sex people or deviant gender behavior, i.e. "sexual inversion", did not denoted the same conceptual phenomenon that "homosexuality". As stated by Halperin, according to the study of the medical literature on the subject done by George Chauncey in 1982-83,

'sexual inversion' referred to a broad range of deviant gender behavior, of which homosexual desire was only a logical but indistinct aspect, while 'homosexuality' focused on the narrower issue of sexual object choice. The differentiation of homosexual desire from 'deviant' gender behavior at the turn of the century reflects a major reconceptualization of the nature of human sexuality, its relation to gender, and its role in one's social definition. (Chancey apud Halperin, 1990: 15)

The investigation of this reconceptualization, form "sexual inversion" to "homosexuality", which explores and brings into focus the formation of subjectivities 
and erotic identities, leads us to the concern of Cultural History with placing at the forefront of the writing of history not anymore the structure, but the individual, not anymore the objective social, but the subjective individual. What reflects the discredit, for the historiography linked to the post-modern changes, of the structural, disembodied and unreal abstractions; the consideration of concrete and singular individuals as "real"; the appreciation of the subjectivity and the personal. The constructionist historiography considers as "real" the concrete and singular individuals; it values the subjectivity to represent manifestations of the individual and no longer demands for the clear and distinct universal. (Reis, 2003: 93)

For Halperin, the evidence of multiple erotic phenomena examined in the Greek documental corpus confirms Foucault's hypothesis that the erotic identities are socially constructed and provides an instigating field of research for the History of Sexuality, mainly with regard to erotic relations between same-sex people, which provided the new advances achieved by the constructionist historiography. In the sequence of the Chapter One of Hundred Years of Homosexuality, the author elaborates a prime argument to that effect to refute the fundamental thesis of John Boswell's works, by which the erotic identities are human essences and therefore tend to universality and naturalness.

By this way of thinking, even well before the emergence of the term homosexuality there were already its practice and identity, just as gravity was already experienced before 1685, the year when Isaac Newton formulated the Law of Universal Gravitation. Boswell claimed that the proposal of Aristophanes' famous myth reported in Plato's Banquet "is to explain why humans are divided into groups of predominantly homosexual or heterosexual interest" (Boswell apud Halperin, 1990: 18). Therefore, for this author, this myth, along with several others from Classical Antiquity, would ensure the existence of homosexuality and heterosexuality as ancient erotic categories (if not universal) of the human experience. His interpretation of the myth leads him to conclude that, according to the Platonic Aristophanes, homosexual and heterosexual interests are "both exclusive as innate" (Boswell apud Halperin, 1990: 19).

Halperin's argumentation to refute Boswell's thesis is cogent. It deconstructs the idea that there could be in Greek culture any indication that the Greeks shared any notion which was remotely similar to what nowadays we might call homo and heterosexuality. Halperin defends the idea that one cannot conclude such division from that myth, since Aristophanes himself didn't point out that conclusion to the consequences of it. On the contrary, that myth helps to illustrate how much the classic Athenians wished to avoid conceptualizing sexual behavior in accordance with a binary opposition that polarized sexual contacts between same-sex people and sexual contacts between opposite-sex people. The counter-arguments are twofold: 
First of all, Aristophanes's myth generates not two but at least three distinct "sexualities" (males attracted to males, females attracted to females, and consigned alike to a single classification, evidently - males attracted to females as well as females attracted to males). Moreover, there is not the slightest suggestion in anything Aristophanes says that the sexual acts or preferences of persons descended from an original female are in any way similar to, let alone congruent or isomorphic with, the sexual acts or preferences of those descended from an original male; hence, nothing in the text allows us to suspect the existence of even an implicit category to which males who desire males and females who desire females both belong in contradistinction to some other category containing males and females who desire one another. (Halperin, 1990: 19-20)

By this way of analyzing the myth, its consequence is to perceive the sexual desire of all human beings as formally identical: all humans would be looking for "a symbolic substitute for an originary object once loved and subsequently lost in an archaic trauma". In this sense, all humans belong to the same "sexuality" and thus no one is individuated at the level of his/her sexual being. (Halperin, 1990: 20)

Second, Aristophanes' account, argues Halperin, "features a crucial distinction within the category of males who are attracted to males, an infrastructural detail missing from his description of each of the other two categories" (Halperin, 1990: 20) Halperin refers to the fundamental characteristics of Greek pederasty, that is, to the condition that such a man is a paiderastes (the adult who loves the young) and a philerastes (the young who is receptive to the adult) at different times of his life, as well as the differences that characterize the "sexualities" of each of these categories ${ }^{12}$. So,

unlike the people comprehended by the first two categories, those descended from an original male are not attracted to one another without qualification; rather, they desire boys when they are men and they take a certain (nonsexual) pleasure in physical contact with men when they are boys. Now since - as the foregoing passage suggests - the classical Athenians sharply distinguished the roles of paederast and philerast, relegating them not only to different age-classes but virtually to different "sexualities", what Aristophanes is describing here is not a single, homogeneous sexual orientation common to all those who descend from an original male but rather a set of distinct and incommensurable behaviors which such persons exhibit in different periods of their lives. (Halperin, 1990: 20)

Representations of identity distinctions in a myth in a philosophical dialogue... Representation is a key concept for cultural history. Roger Chartier, an author definitely

\footnotetext{
${ }^{12}$ For further analysis of the differences between the categories paiderastes and philerastes, see Halperin, 1990, note 31 of Chapter "One hundred years of homosexuality"; Barbo, 2008, capítulo 3: $\mathrm{O}$ homoerotismo na cultura falocêntrica.
} 
associated with the New Cultural History, thinks that the importance of this notion is to allow the articulation of

[...] three levels of reality: first, on the level of collective representations that embody, within individuals, the divisions of the social world and organize the schemes of perception by which individuals classify, judge and act; second, on the level of forms of exhibition and stylization of the identity that those individuals or groups hope will be recognized; third, on the level of the delegation to representatives (single individuals, institutions, or abstract instances) of the coherence and stability of the identity thus affirmed.

The history of the construction of social identities thus becomes a history of relations of symbolic forces. It defines the construction of the social world as the success (or failure) of the works that groups perform on themselves - and on others - to transform the objective properties common to their members into a "belonging" that is perceived, demonstrated, and recognized (or denied). It understands symbolic domination as the process by which the dominated accept or reject the identities imposed on them with a view to ensuring and perpetuating their subjection. (Chartier, 1997: 5)

Erotic identities are socially constructed and their representations encode on the diversity of cultural products. Regarding the analyzed myth, Halperin evidences those records of articulated reality through the representations, stating that "the picture drawn by Plato's Aristophanes is a historically accurate representation of the moral conventions governing sexual behavior in Classical Athens, if not the reality of sexual behavior itself". (Halperin, 1990: 160, note 31)

Halperin establishes some basic points about the erotic act in Classical Athens. Briefly, they can be listed as follows: (i) the erotic act is not inherently relational or collaborative; (ii) it is deeply polarizing and hierarchical: it effectively splits, classifies and distributes its participants into two distinct and radically opposing categories: the active and the passive sexual role; (iii) it is linked to politics, expressing power relations, i.e. active and passive erotic categories are socially and politically articulated. (Halperin, 1990: 29-30)

In Classical Athens, the male public discourse tends to represent the erotic act, first, not as a shared collective act, but as an action performed by one person on another. It does not generate a relation of mutuality, but an act or an impact in accordance with the participant's viewpoint. So it does not have an intrinsically relational or collaborative nature. On the contrary, it is a personal domination, whose nature is unilateral. Second, precisely because it is conceived as essentially centered on the asymmetrical act of the phallic penetration, the erotic act is a deeply polarizing experience, splitting, classifying and distributing the participants in different and radically opposed categories, namely, the insertive or active partner and the receptive or passive partner. Since the insertive partner is interpreted as an erotic agent, whose phallic penetration 
expresses erotic 'activity', while the receptive partner is interpreted as an erotic patient, whose submission to the phallic penetration expresses erotic 'passivity', the erotic act is also hierarchical.

Finally, this hierarchy expresses a socio-political domination. The erotic relationship between the active and passive partners reproduces the relationship set up between superior and subordinate in social and political spheres. There is established, thus, an isomorphism between the erotic role of an individual and his socio-political status. This implies that an adult male citizen can only have legitimate erotic relations with people of low socio-political status, i.e., women, boys, foreigners or slaves. An erotic act redoes the differential in socio-political status that distinguishes the partners involved: the authority and prestige of the adult male citizen were expressed in his erotic privilege - in his power to initiate an erotic act, in his right to get pleasure through this act and in the precedence itself of the erotic insertive role.

So, for an erotic contact between two men be considered legitimate and reputable, the persons involved must not possess the same socio-political status. The relationship erastés/erómenos, or paederasty, must include mandatorily a person of higher status and a person of lower status. In addition, in this relationship the erotic acts must be congruent with the power differential according to which the relationship has been structured. This implies that the higher partner took sexual precedence - only he could start an erotic act, penetrate the body of his partner and get erotic pleasure.

The lack of social reciprocity in the relationship leads to a lack of erotic reciprocity, and both were necessary. In his analysis, Halperin comes to a very important conclusion as it reveals the cultural interdependence between 'social practices' and 'subjective experiences':

The Greek record suggests that sexual choices do not always express the agent's individual essence or reveal the profound orientation of the inner life of a person, independent of social and political life. Quite the contrary: the sexual identities of the classical Athenians - their experiences of themselves as sexual actors and as desiring human beings - seems to have been inseparable from, if not determined by, their public standing. (Halperin, 1990: 32-33).

Thus, the ars erotica ${ }^{13}$ of the classical Athenians cannot be understood if it is described as an autonomous sphere of life governed by its own internal laws. The attitudes and

${ }^{13}$ See Michel Foucault, The history of sexuality, 1978. The modern West is not the first place to develop a discourse about the truth of sex. The cultures of Rome, China, Japan, India, and the ArabicMuslim world, have all treated sex as an object of knowledge. However, Foucault distinguishes these 
erotic practices of that art only reveal their systematic coherence if we locate them in the wider social context in which they are immersed, since the erotic sphere of the classical Athenians, far from being independent or separated from politics, was composed by the same principles by which the Athenian public life was organized. (Halperin, 1990: 31)

Unlike the modern Western world, where the sexual categories (homo-, hetero- and bisexuality) are articulated by 'sexuality', seen as an autonomous ideological sphere and not related so directly with socio-political issues, the Classical Athens held a culture in which the erotic categories (active and passive) were articulated by relations of power and honor and cannot be understood without reference to them.

Thereby, the Athenian categories active and passive must not be thought of only as erotic categories, but as socio-erotic categories, because they express an erotic position and a position in the socio-political hierarchy. Citizenship for Athenian males, therefore, was a sociopolitical concept (and an experience) articulated simultaneously to the genre and the erotic practice. (Halperin, 1990: 11)

From this, Halperin was able to establish that in Classical Athens prevailed a complex structure which articulated close and intimately erotics and political power. This structure grants Athenian citizens at full maturity of phallic activity (insertive erotic role) the exclusive right to political voice and access to public space. These privileges were refused to the other members of the citizenship (women and youth) and other members of the community (slaves and foreigners), all of them in real or potential submission to the phallus by the passivity (receptive erotic role). So, the links between erotics and political power merge in the polarity active/passive, what makes identifying masculinity with phallic activity (the act of penetrating whoever, male or female) and considering voluntary erotic passivity, the condition identified with the political inferiority, an unworthy submissive act for male Athenian citizens, since such desire represents a voluntary abandonment of a masculine identity in favor of a female identity, violating the sense of congruence, deeply felt and anxiously advocated,

societies from our own by saying they deal in an ars erotica (erotic art) whereas we deal in a scientia sexualis (science of sexuality). The knowledge passed on by the ars erotica is a knowledge of sensual pleasure. The truth it contains is the truth about pleasure itself: how pleasure can be experienced, intensified or maximized. A mystique and secrecy evolves around this knowledge, and it can only be passed from an experienced master to an initiated novice. There is no question of what pleasures are permitted and what forbidden: only a question of the pleasures themselves. The scientia sexualis, by contrast, deals with confessions extracted from the unlearned rather than secrets passed down from the learned. Since the Middle Ages, Foucault asserts, confession has become increasingly important to us. In law, we demand the confession of criminals; in literature, we relish self- conscious confession; in philosophy, we have increasingly come to see truth as something to be dug out of our own consciousness. 
between gender, erotic practices and social identity of a person in the Greek world. Therefore, this male erotic culture establishes an erotic asymmetry structured by, and simultaneously structuring of, a socio-political asymmetry. The erotic behavior, much more than express someone's internal inclinations or dispositions, served to position social actors in the places designated for them in the hierarchical structure of Athenian politics and society.

Thus, the power of this male erotic culture was put into operation through a complex device responsible for a double domination: an erotic dominance configured by a socio-political dominance. And this domination is constituted around the phallus, not just as penis or a mere equipment of the male anatomy, but as a socio-political power symbol culturally constructed by the Greek erotic discourse ${ }^{14}$.

${ }^{14}$ Halperin, 1990, Chapter 1, note 83, called the Greek sexual discourse phallic because "(1) sexual contacts are polarized around phallic action - i.e., they are defined by who has the phallus and by what is done with it; (2) sexual pleasures other than phallic pleasures do not count in categorizing sexual contacts; (3) in order for a contact to qualify as sexual, one - and no more than one - of the two partners is required to have a phallus (boys are treated in paederastic context as essentially un-phallused and tend to be assimilated to women [...] By 'phallus' I mean a culturally constructed signifier of social power $[\ldots] "$ 


\section{Conclusion}

The constructionist historiography of Greek erotics is clearly rooted in the New Cultural History. Those historians "advocate and practice the description of the plurality of objects and methods." (Reis, 2003: 76) In Reis' analysis of the process from global history to history in pieces, we verify the passage from social science-based History to literature-based History, which could make the historical knowledge "more flexible, more qualitative, more poetic, more personal, more imaginative and freer. History broke free from the rigor of science, which actually was a false rigor". (Reis, 2003: 94) One of the fundamental techniques of the method created by the constructionist authors, the Cultural Poetics of Desire, is taken from the methodological arsenal of literary criticism:

Literary critics, surveying the field of literary production, describe the prevailing (and the countervailing) artistic strategies for combining and ordering literary elements to construct various kinds, or genres, of literary artworks. Some cultural critics are now using analogous techniques to describe the procedures whereby meaningful forms of collective experience are socially constructed, often by a reconstitution of inherited components. (Halperin; Winkler; Zeitlin, 1990: 4)

Also, this historiography reflects the changes that are displacing and fragmenting identities, which are putting in collapse the stability, the fixity and the uniqueness of the modern relation between subject and structure ${ }^{15}$, which results in the refusal of the metaphysics and the traditional philosophical history; which results in the belief in "the possibility of an effective observation of any object in micro scale" (Reis, 2003: 92); which results in considering the overview as totalitarian and threatening individual liberties; which results in the belief "that the intervention in society should be localized and punctual, without ambitions of global revolutionary changes" (Reis, 2003: 92), what Reis considers to be the "passage of the whole (holism) to everything (micro)" (Reis, 2003: 92). In the introduction of Before Sexuality, Zeitlin says:

So described, the project may sound very ambitious, perhaps even presumptuous, and so we hasten to disclaim any pretense of practicing some universal science of humanity. Indeed, we tend to be suspicious of claims to see and comprehend the whole, any whole; it will be quite enough if we are able to illuminate parts or aspects of our subject. This volume then, does not aspire to provide a comprehensive survey of ancient Greek sex, much less sexuality. The sketches it contains are avowedly pluralistic, partial, and

${ }^{15}$ See Hall; Held; Hubert; Thompson, 1996, Identity in question, p. 596-631.

Revista Heródoto. Unifesp. Guarulhos, v. 01, n. 01. Março, 2016. p. 265-298. 
discontinuous - a series of glimpses, as it were, through different peepholes placed in the walls around a large construction site. Coming from different directions but working together, we hope to provide a series of progress reports on some of the major modes - religious, social, political, philosophical, medical, literary, and artistic - in which sexual experience was constructed and reflected by Greek-speaking people living in and around the Mediterranean basin from archaic times through the Roman Empire. (Halperin; Winkler; Zeitlin, 1990: 4-5)

Furthermore, we can check on Reis' analysis, the passage from the material to the imagery and symbolic, that is, the appreciation of the psychological and intimate world of individuals and collectives; the appreciation of beliefs and superstitions, fears and fantasies, dreams and nightmares. (Reis, 2003: 93)

The emergence of postmodern subject that takes shape from the rampant fragmentation of identities in the new reality brought by the second half of the twentieth century guides Winkler in his cultural anthropology of sex and gender in ancient Greece. The Feminist Criticism molds his worry to demystify the Greek male discourses crystallized in the androcentric protocols of Greek culture.

The emergency of pungent issues related to identity multiplication, diversification and contradiction posed by social developments and displacements promoted by the late modernity emerge in Halperin's analysis.

In terms of erotic identity manifestations, "a moment when the strong temptations of identitarian history risk muddying all distinction between a universally acceptable, verified knowledge and the mythical reconstructions that sustain particular memories and aspirations" (Chartier, 1997: 8), Boswell's interpretation suffers from the same malady that Eric J. Hobsbawm alerts us in relation to the imagined communities:

Reading the desires of the present into the past, or, in technical terms, anachronism, is the most common and convenient technique of creating a history satisfying the needs of what Benedict Anderson has called 'imagined communities' or collectives, which are by no means only national ones. (Hobsbawn apud Chartier, 1997: 8)

If John Boswell still wanted the clarity of structure, the universal distinction, the essence of the identity, which are some typical values of the modern thought, Halperin is concerned with the multiple and complex manifestations of the identities. He returns to the Platonic Aristophanes's myth with other questions, with the enlightened eyesight for other issues that only the pressure of the displacements of postmodern subject could provide. 


\section{Bibliography}

AESCHINES. Against Timarchus. Cambridge \& London: Harvard University Press \& William Heinemann Ltd., 1988.

BARBO, Daniel. Detratores do homoerotismo grego: uma historiografia essencialista. História da historiografia, Ouro Preto, número 6, março, 2011, 171-188.

BARBO, Daniel. Michel Foucault e a Historiografia Construcionista. E-hum, Belo Horizonte, Editora uniBH. Vol. 4, N. 2, 2011, 21-41.

BARBO, Daniel. O Triunfo do Falo: Homoerotismo, Dominação, Ética e Política na Atenas Clássica. Rio de Janeiro: E-Papers, 2008.

BOSWELL, John. Christianity, social tolerance and homosexuality: gay people in western Europe from the beginning of the Christian Era to the fourteenth century. Chicago and London: The University of Chicago Press, 1980.

BOSWELL, John. Same-sex unions in premodern Europe. New York: Vintage Books, 1994.

BURKE, Peter. O que é História Cultural? Rio de Janeiro: Zahar, 2005.

CHARTIER, Roger. On the edge of the cliff: history, languages and practices. Baltimore and London: The John Hopkins University Press, 1997.

DOVER, K. J. Review: Greek Sexual Choices. Reviewed work: One Hundred Years of Homosexuality and Other Essays on Greek Love by David M. Halperin. The Classical Review, New Series, Vol. 41, No 1, (1991), pp. 161-162.

FOUCAULT, Michel. The history of sexuality. Volume 1: an introduction. New York: Pantheon Book, 1978.

FOUCAULT, Michel. História da sexualidade: a vontade de saber. $13^{a}$ edição, Rio de Janeiro: Graal, 1988.

FOUCAULT, Michel. História da sexualidade: o uso dos prazeres. Rio de Janeiro: Graal, 1984.

FOUCAULT, Michel. História da sexualidade: o cuidado de si. Rio de Janeiro: Graal, 1985.

FREUD, Sigmund. A Interpretação dos Sonhos. Rio de Janeiro: Imago, 2001.

GINZBURG, Carlo. O fio e os rastros. São Paulo: Companhia das Letras, 2007.

Revista Heródoto. Unifesp. Guarulhos, v. 01, n. 01. Março, 2016. p. 265-298. 
GOLDHILL, Simon. [untitled] Reviewed work: Before Sexuality: The construction of Erotic Experience in the Ancient Greek World by David M. Halperin; John J. Winkler; Froma I. Zeitlin. The Classical Review, New Series, Vol. 41, No 1, (1991), pp. 159-161.

HALL, Stuart. A identidade cultural na pós-modernidade. 11ª ed., Rio de Janeiro: DP\&A, 2006.

HALL, Stuart; HELD, David; HUBERT, Don; THOMPSON, Kenneth. Modernity: an introduction to modern societies. Wiley-Blackwell, 1996.

HALPERIN, David M. One hundred years of homosexuality and other essays on Greek love. New York, London: Routledge, 1990.

HALPERIN, David M.; WINKLER, John J.; ZEITLIN, Froma I. Before sexuality: the construction of erotic experience in the Greek world. Princeton: Princeton University Press, 1990.

KOSELLECK, Reinhart. Futuro passado: contribuição à análise dos tempos históricos. Rio de Janeiro: Contraponto: Ed. Puc-Rio, 2006.

LAIPSON, Peter. Review: From Boudoir to Bookstore: Writing the History of Sexuality. A Review Article. Reviewed Work: One Hundred Years of Homosexuality by David M. Halperin, Making Sex by Thomas Laqueur, Passion and Power by Kathy Peiss; Christina Simmons; Robert A. Padgug, Romantic Longings by Steven Seidman. Comparative Studies in Society and History, Vol. 34, no 4, (Oct., 1992), pp. 636-644.

REIS, José Carlos. História \& Teoria: Historicismo, Modernidade, Temporalidade e Verdade. Rio de Janeiro: Editora FGV, 2003.

SUTTON Jr., Robert F. [untitled] Reviewed works: Before Sexuality: The construction of Erotic Experience in the Ancient Greek World by David M. Halperin; John J. Winkler; Froma I. Zeitlin; One Hundred Years of Homosexuality and Other Essays on Greek Love by David M. Halperin; The Constraints of Desire: The Anthropology of Sex and Gender in Ancient Greece by John J. Winkler. The Classical Journal, Vol. 87, $\mathrm{n}^{\mathrm{o}} 2$, (Dec., 1991 - Jan., 1992), pp. 189-191.

THORP, John. The Social Construction of Homosexuality. Phoenix, Vol. 46, n 1 , (Spring, 1992), pp. 54-61.

VERSTRAETE, Beert C. [untitled] Reviewed works: One Hundred Years of Homosexuality and Other Essays on Greek Love by David M. Halperin; The Constraints of Desire: The Anthropology of Sex and Gender in Ancient Greece by John J. Winkler; Before Sexuality: The construction of Erotic Experience in the Ancient Greek World by David M. Halperin; John J. Winkler; Froma I. Zeitlin. Journal of the History 
of Sexuality, Vol. 2, $\mathrm{n}^{\circ}$ 2, Special Issue, Part 1: The State, Society, and the Regulation of Sexuality in Modern Europe, (Oct., 1991), pp. 289-293.

WINKLER, John J. Las coacciones del deseo: antropología del sexo y el género en la antigua Grecia. Buenos Aires: Manantial, 1994.

WINKLER, John J. The constraints of desire: the anthropology of sex and gender in Ancient Greece. New York, London: Routledge, 1990 